\title{
Distribution and infection of triatomines (Hemiptera: Reduviidae) by Trypanosoma cruzi in the state of Michoacán, Mexico
}

\author{
José Alejandro Martínez-Ibarra ${ }^{1 /+}$, Ignacio Valencia-Navarro ${ }^{2}$, Salvador León-Saucedo ${ }^{2}$, \\ Gabriela Ibáñez-Cervantes ${ }^{3}$, Rafael Bustos-Saldaña', Oziel Dante Montañez-Valdez', \\ Óscar Iván Cervantes Díaz ${ }^{1}$, Benjamín Nogueda-Torres ${ }^{3}$
}

\begin{abstract}
Área de Entomología Médica, Centro Universitario del Sur, Universidad de Guadalajara, AP 20, 49000 Ciudad Guzmán, Jalisco, México ${ }^{2}$ Servicios de Salud en el Estado de Michoacán, Morelia, Michoacán, México ${ }^{3}$ Comisión de Operación y Fomento de Actividades Académicas, Instituto Politécnico Nacional, Escuela Nacional de Ciencias Biológicas, Colonia Casco de Santo Tomás, México DF, México
\end{abstract}

An entomological study of triatomine species was carried out to assess their prevalence in 10 localities of the state of Michoacán, Mexico. Entomological indices were calculated to estimate the risk for vector-borne transmission of Trypanosoma cruzi to the human population in this area. Four triatomine species (Triatoma barberi, Triatoma dimidiata, Meccus pallidipennis and Meccus longipennis) were collected from the study area. This is the first report of M. longipennis and T. dimidiata in Michoacán. M. pallidipennis was significantly $(p<0.05)$ more abundant than any of the other species collected in the study area. Infection indices were greater than $50 \%$ for each of the four collected triatomine species. Significantly more triatomines were collected from intradomiciliary areas than from peridomiciliary or sylvatic areas. Infestation, crowding and density indices were low, whereas colonisation indices were high in five localities. The current vectorial conditions in the study area require continuous entomological and serological surveillance to diminish the risk of $\mathrm{T}$. cruzi transmission to human populations.

Key words: Triatominae - Chagas disease - Michoacán - Mexico

In Mexico, at least 1.5 million inhabitants are infected with Trypanosoma cruzi, and this number rises by almost 70,000 new cases each year. The primary $(96 \%)$ route of infection for T. cruzi in humans is vectorial transmission. There are more than 70 million people living in endemic areas who are at risk of becoming infected and at least 20 million more are put at risk by visiting these areas. Eight Mexican states are the source of $69 \%(931,643)$ of all serologically positive human cases of Chagas disease in Mexico and, of these, the state of Michoacán has almost 100,000 of those cases (Ramsey et al. 2003). In Michoacán, the presence of Meccus (former Triatoma) pallidipennis (Stål) and Meccus mazzottii (Usinger), which are of the Phyllosoma complex and proposed subspecies of Meccus phyllosomus (Burmeister) (Bargues et al. 2008, Martínez-Ibarra et al. 2008b, 2009, Martínez et al. 2010), are responsible for $67 \%$ of vectorial transmissions of $T$. cruzi to humans in Mexico (Zárate \& Zárate 1985). There also exists Triatoma barberi Usinger, which is responsible for $3 \%$ of vectorial transmissions of T. cruzi to humans in Mexico (Ramsey et al. 2003).

Although Michoacán is a state with endemic T. cruzi infections, no recent entomological data on triatomines has been gathered. However, this is not the case for each of the neighbouring and western states (Colima, Guanajuato, Querétaro, Guerrero, Jalisco, Nayarit, Aguascalientes and Estado de México), where the study of vectors

+ Corresponding author: aibarra@cusur.udg.mx

Received 26 December 2010

Accepted 6 May 2011 for T. cruzi is considered important (Espinoza-Gómez et al. 2002, López-Cárdenas et al. 2005, Villagrán et al. 2008, Licón-Trillo et al. 2010, Martínez-Ibarra et al. 2010a, b, Medina-Torres et al. 2010, Rodríguez-Bataz et al. 2011). These studies have led to a clear epidemiological picture of Chagas disease in western and central Mexico, with the exception of Michoacán. Therefore, this entomological study was carried out in Michoacán to determine the current distribution of triatomines and their rates of infection with $T$. cruzi in this area.

\section{MATERIALS AND METHODS}

The study was performed during 2009. The following 10 localities from 10 municipalities were selected for the study: Tiquicheo $\left(18^{\circ} 54^{\prime} \mathrm{N} 100^{\circ} 47^{\prime} \mathrm{W}\right)$ from the municipality of Tiquicheo, Tuzantla $\left(19^{\circ} 32^{\prime} \mathrm{N} 100^{\circ} 37^{\prime} \mathrm{W}\right)$ from Tuzantla, Turicato $\left(19^{\circ} 05^{\prime} \mathrm{N} 101^{\circ} 27^{\prime} \mathrm{W}\right)$ from Turicato, Taretan $\left(19^{\circ} 23^{\prime} \mathrm{N} 101^{\circ} 57^{\prime} \mathrm{W}\right)$ from Taretan, Nuevo Urecho $\left(19^{\circ} 12^{\prime} \mathrm{N} 101^{\circ} 50^{\prime} \mathrm{W}\right)$ from Nuevo Urecho, Nuevo Capirio (19 $\left.48^{\prime} \mathrm{N} 102^{\circ} 12^{\prime} \mathrm{W}\right)$ from Mugica, Crucero de Parácuaro $\left(19^{\circ} 35^{\prime} \mathrm{N} 101^{\circ} 30^{\prime} \mathrm{W}\right)$ from Parácuaro, Los Limones $\left(19^{\circ} 03^{\prime} \mathrm{N} 102^{\circ} 16^{\prime} \mathrm{W}\right)$ from Los Reyes de Salgado, San Isidro (19 $\left.06^{\prime} \mathrm{N} 102^{\circ} 51^{\prime} \mathrm{W}\right)$ from Tepalcatepec and La Palma $\left(20^{\circ} 12^{\prime} \mathrm{N} 101^{\circ} 44^{\prime} \mathrm{W}\right)$ from the municipality of Venustiano Carranza (Figure). La Palma is located on the shores of Lake Chapala, which is the largest lake in Mexico. This area is known as the Ciénega region and it is composed of 16 municipalities epidemiologically relevant for Chagas disease (Gómez-Hernández et al. 2008). Approximately $80 \%$ of this area belongs to the state of Jalisco, while the remainder is within the Michoacán (SEGOB 2010). Interestingly, prior to this study, the region of La Palma in the Michoacán was the only area that had not been evaluated for the presence of triatomines. 
Triatomines have been found to exist in many of the study localities (Zárate \& Zárate 1985), although the descriptions provided by the local health sanitary authorities were poor (Orozco-Mosqueda 2003). For this study, the localities selected represent the majority of Michoacán territory as well as the many diverse habitats of triatomines (pine forest, arid areas, rural and urban areas) (SEGOB 2010).

In total, 12 field trips (1 per month) lasting three days each were made to each village. Triatomines were searched for using a map of each locality and 8.3-38.1\% of the households in each village were selected at random using the Epi Info 6.04 package (CDC, Atlanta, GA, USA). In each selected human dwelling, intradomiciliary and peridomiciliary areas, as well as natural ecotopes, were searched. Sampling was performed in all natural ecotopes of triatomines, which include bird nests, hollow trees and cracks, holes in the ground, railings, rock pile boundary walls, heaps of stones and hollows in caves. The presence or absence of triatomines in each residence was determined by the results of $20 \mathrm{~min}$ intradomicile and 20 min peridomicile timed manual collections of adult or nymphal triatomines. Daytime searches were conducted by spraying an irritant insecticide and then using a flashlight to look into cracks and crevices throughout the interior of the buildings, in cupboards, behind pictures on walls and under furniture and bedding. A team of three trained personnel conducted the searches on each house selected from each village. The intradomiciliary (domestic) area was defined as the interior of houses and attached buildings, which included all rooms circumscribed by the main walls of the dwelling where inhabitants normally sleep. The peridomiciliary (peridomestic) area was defined as the area surrounding the homestead, which was usually enclosed by a fence and often contained features such as rocks, mounds of construction materials, animal shelters and agricultural products. Consequently, human dwellings (intradomiciliary and peridomiciliary areas) included the area from the main building of the dwelling to the fences (20-30 m)

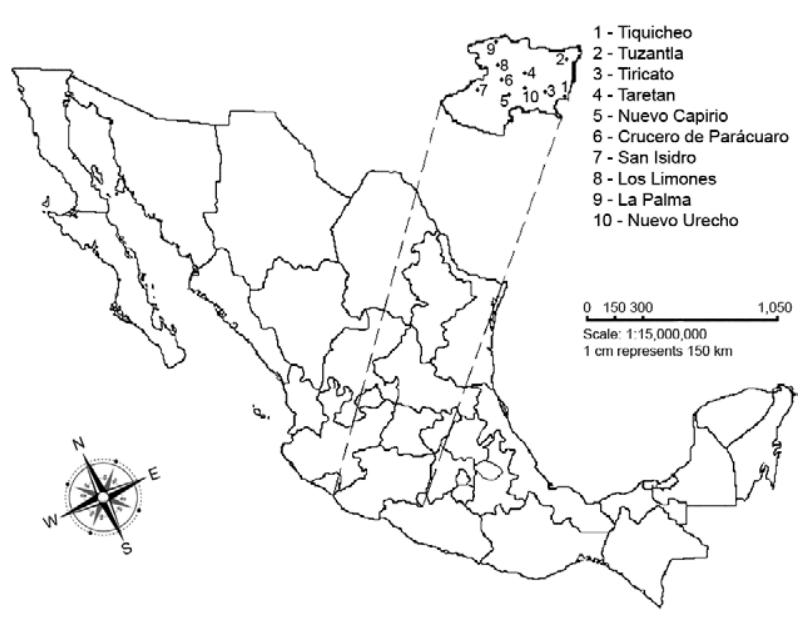

Studied localities in the state of Michoacán, Mexico.
(Cohen et al. 2006). Sites beyond the fences were considered sylvatic habitats. In addition, 30 wire-net bait traps, each containing a Wistar rat, were used. These were similar to Noireau traps (Noireau et al. 2002) but were modified by Martínez-Ibarra et al. (2008a). Traps were placed overnight in 15 sylvatic and 15 peridomestic sites that included natural bug ecotopes described previously. Triatominae were collected by hand during the day, with the aid of flashlights, and were placed inside plastic containers labelled with collection data (place of capture and sex) using tweezers.

Triatomines were collected live and transported to the laboratory, where they fed on hens and were placed individually in Petri dishes until defecation. Triatomine infection with $T$. cruzi was determined by microscopic examination of the faeces. Parasites detected in the faeces were collected and intraperitoneally inoculated into Swiss mice. For a detailed description of T. cruzi infection in the area and among species, the infections were reported by species and instar. Adults were classified as males and females, younger nymphs were classified as first to third instars and older nymphs as fourth and fifth instars. Identification of triatomine species was made using the keys from Lent and Wygodzinsky (1979) and Alejandre-Aguilar et al. (1999), while taking into account the reclassification of the genus Meccus (Carcavallo et al. 2000, Bargues et al. 2008).

The entomological indices were calculated for village and species using the methods of Silveira et al. (1984), whereas the crowding and density indices were calculated using a subsequent modification of the method (Pinto-Dias \& Gonçalves-Diotaiuti 1998). Data were analysed using the Epi Info 6.04 package. Chi-square tests were used to compare distribution across several categories. Differences were considered significant when $\mathrm{p}<0.05$ and the Bonferroni correction was applied for appropriately sized groups.

\section{RESULTS}

In total, 835 triatomines of the genera Triatoma $[(T$. barberi and T. dimidiata (Latreille)] and Meccus (M. longipennis and $M$. pallidipennis) were collected from the study area. This is the first report of $M$. longipennis and T. dimidiata in Michoacán. We were unable to collect $M$. mazzottii specimens, despite previous reports of this species in the study area. The most abundant species was $M$. pallidipennis $(83.5 \%, \mathrm{n}=835)$, whereas the least abundant were T. barberi (3.1\%) and T. dimidiata (1.2\%). Rates of infection with $T$. cruzi were greater than $50 \%$ in all of the species examined. These were highest in $T$. dimidiata and $T$. barberi, but these differences were not significant (Table I). Significantly more total specimens were collected from intradomiciliary areas than from peridomiciliary or sylvatic areas. However, more specimens of T. barberi $(85 \%, \mathrm{n}=26)$ were collected from peridomiciliary areas (Table II). Infestation indices were low (under 10\%) in most localities, but were significantly greater in Taretan $(23 \%, \mathrm{n}=100)$. Colonisation indices were approximately $20 \%$ or more in most localities, but again, were signifi- 
TABLE I

Natural infection (NI) by Trypanosoma cruzi by species and instars on triatomines collected in the state of Michoacán along 2009

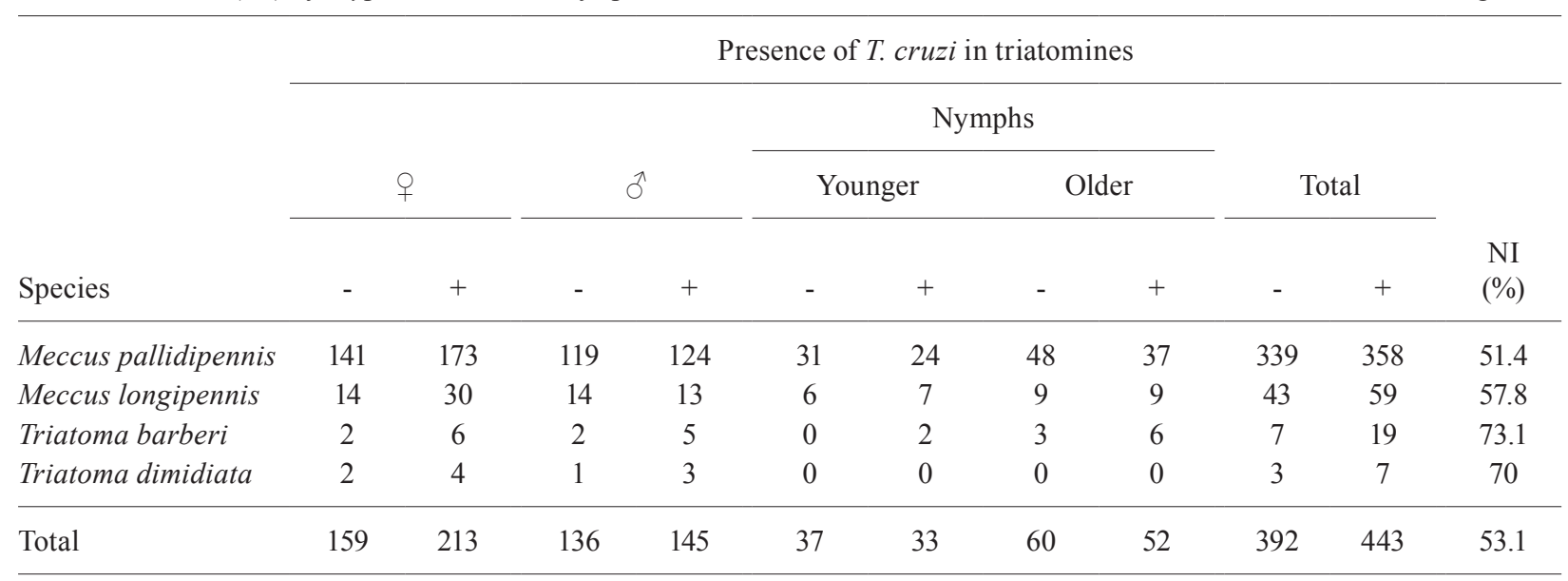

TABLE II

Triatomine species according to the collection area in the state of Michoacán along 2009

\begin{tabular}{|c|c|c|c|c|c|c|c|}
\hline \multirow[b]{3}{*}{ Triatomine species } & \multirow[b]{3}{*}{$\mathrm{n}$} & \multicolumn{6}{|c|}{ Collection area } \\
\hline & & \multicolumn{2}{|c|}{ Intradomiciliary } & \multicolumn{2}{|c|}{ Peridomiciliary } & \multicolumn{2}{|c|}{ Sylvatic } \\
\hline & & $\mathrm{n}$ & $\%$ & $\mathrm{n}$ & $\%$ & $\mathrm{n}$ & $\%$ \\
\hline Meccus pallidipennis & 697 & 541 & 77.6 & 135 & 19.4 & 21 & 3 \\
\hline Meccus longipennis & 102 & 73 & 71.6 & 25 & 24.5 & 4 & 3.9 \\
\hline Triatoma barberi & 26 & 4 & 15.4 & 22 & 84.6 & 0 & 0 \\
\hline Triatoma dimidiata & 10 & 10 & 100 & 0 & 0 & 0 & 0 \\
\hline Total & 835 & 628 & 75.2 & 182 & 21.8 & 25 & 3 \\
\hline
\end{tabular}

cantly greater in Taretan $(91 \%, \mathrm{n}=23)$. Crowding indices were also low (greater than 8 ) in most of the communities and were greatest in Turicato (17.7) and Tuzantla (18.3). The density indices were less than 1 in most localities (Table III). Specimens of two sympatric species were collected from Taretan (M. pallidipennis and T. dimidiata) and La Palma (M. longipenis and T. barberi).

\section{DISCUSSION}

More than 800 triatomines were collected from the study area. This number is similar to that collected from the neighbouring state of Jalisco, where populations of the same species of triatomines as those studied here have recently been reported (Gómez-Hernández et al. 2008, Martínez-Ibarra et al. 2008a). The most common species found throughout the study area was $M$. pallidipennis, which was collected most often from houses with cement-covered adobe walls and tile roofs. Similar results were obtained from the northwestern neighbouring state of Colima and from the eastern neighbouring states of Estado de México and Guerrero (Espinoza-Gómez et al.
2002, Medina-Torres et al. 2010, Rodríguez-Bataz et al. 2011). M. pallidipennis is also present in the northeastern neighbouring state of Querétaro, in the western neighbouring state of Jalisco and in the northern of Guanajuato, where it has been sympatrically collected with M. longipennis (López-Cárdenas et al. 2005, MartínezIbarra et al. 2009). These three states are considered to be the western and northern limits for the distribution of M. pallidipennis and other species [Triatoma mexicana (Herrich-Scaeffer) and M. longipennis] are more common here (López-Cárdenas et al. 2005, Villagrán et al. 2008, Martínez-Ibarra et al. 2010a). Greater than 50\% of the $M$. pallidipennis specimens analysed tested positive for T. cruzi infection, which demonstrates the epidemiological importance of this species in the study area. High infection indices for populations of $M$. pallidipennis have also been recorded in the states of Colima, Morelos, Jalisco, Estado de México and Guerrero (EspinozaGómez et al. 2002, Villegas-García \& Santillán-Alarcón 2004, Martínez-Ibarra et al. 2008a, Medina-Torres et al. 2010, Rodríguez-Bataz et al. 2011). 
TABLE III

Entomological indices ${ }^{a}$ per locality in the state of Michoacán along 2009

\begin{tabular}{|c|c|c|c|c|c|c|c|}
\hline \multirow[b]{2}{*}{ Locality } & \multicolumn{2}{|c|}{ Houses } & \multicolumn{5}{|c|}{ Indices } \\
\hline & Searched & $\begin{array}{l}\text { Total at the } \\
\text { locality (\%) }\end{array}$ & Infestation & Colonisation & Crowding & Density & $\begin{array}{l}\text { NI } \\
(\%)\end{array}$ \\
\hline San Isidro & 70 & 32.7 & 11 & 25 & 7.8 & 0.9 & 66 \\
\hline Crucero de Parácuaro & 90 & 35.6 & 8 & 29 & 8.0 & 0.6 & 18 \\
\hline Nuevo Urecho & 93 & 34.1 & 5 & 20 & 10.6 & 0.6 & 45 \\
\hline Taretan & 100 & 8.3 & 23 & 91 & 7.1 & 1.6 & 60 \\
\hline Nuevo Capirio & 89 & 26.4 & 6 & 20 & 9.8 & 0.6 & 63 \\
\hline Turicato & 93 & 22.7 & 8 & 14 & 17.7 & 1.3 & 50 \\
\hline Tiquicheo & 83 & 13.1 & 8 & 29 & 8.6 & 0.7 & 55 \\
\hline Los Limones & 94 & 38.1 & 10 & 20 & 8.6 & 0.9 & 44 \\
\hline La Palma & 69 & 9.22 & 7 & 20 & 8.5 & 1.9 & 61 \\
\hline Tuzantla & 92 & 18 & 3 & 33 & 18.3 & 0.6 & 54 \\
\hline
\end{tabular}

$a$ : Silveira et al. (1984); NI: natural infection.

M. longipennis was found only in the Ciénega region of La Palma and mostly was found inside houses built with cement-covered adobe walls and concrete roofs. Although this species has not previously been reported in Michoacán, its presence is not surprising because it has been collected from other parts of the Ciénega region and from other nearby areas in Jalisco (GómezHernández 2008, Martínez-Ibarra et al. 2009). In contrast, no specimens of $M$. mazzottii were collected from the Ciénega region, where they have been previously reported (Zárate \& Zárate 1985). However, some M. longipennis specimens collected had an unusual red colour (instead of the typical orange) in the connexivum, which is similar to the typical colouring of M. mazzottii. It is therefore possible that the previous identification of $M$. mazzottii in Michoacán (Zárate \& Zárate 1985) may have been a mistake that was caused by the misidentification of atypical $M$. longipennis specimens.

M. longipennis was the most common species $(79.7 \%$, $\mathrm{n}=128)$ in La Palma. This prevalence is similar to that previously reported for the Ciénega region (55.4\%) (Gómez-Hernández 2008) and to other areas in Jalisco (Martínez-Ibarra et al. 2010a). Almost $60 \%$ of specimens were infected with $T$. cruzi, which is also similar to those previously studied in the Ciénega area (71.05\%) (Gómez-Hernández et al. 2008) and in the neighbouring region of Jalisco (52\%) (Breniere et al. 2010).

T. barberi was also found only in La Palma and was mainly found in exterior concrete walls and on amassed tiles. This species was not found in the eastern area of Tuzantla, although previous studies have reported its presence here (Zárate \& Zárate 1985). T. barberi was found to be very scarce throughout the entire study area, which is consistent with previous reports from the western neighbouring state of Jalisco (Martínez-Ibarra et al. 2008a, 2010a). More than 70\% $(\mathrm{n}=26)$ of the T. barberi specimens were infected by $T$. cruzi. This value is similar to infection rates found throughout the Ciénega region $(87.8 \%)$ and from a neighbouring area of Jalisco (53.2\%) (Martínez-Ibarra et al. 2010a).

This study is the first to report the identification of T. dimidiata and M. longipennis in Michoacán. However, T. dimidiata was found to be scarce throughout the study area. In Taretan, this species was only collected from two human dwellings made of concrete walls and tile roofs and it had an infection index of $70 \%(n=10)$. The limited presence of $T$. dimidiata in Michoacán is compatible with the proposed existence of "islands" where this species is found that are considered epidemiologically unimportant (Ramsey et al. 2003). These exist in certain western (Colima, Jalisco), central (Guanajuato, Querétaro, Estado de México) and southern (Guerrero) states of Mexico (Espinoza-Gómez et al. 2002, López-Cárdenas et al. 2005, Gómez-Hernández et al. 2008, Villagrán et al. 2008, Medina-Torres et al. 2010, Rodríguez-Bataz et al. 2011). It is likely that the limited number of specimens collected in these areas had been passively transported by sugar cane (Saccharum officinarum L), as the sugar mill in Taretan receives sugar cane plants from some very distant locations that have not been evaluated for triatomine species. Similar phenomena have been recorded in Colima and Guanajuato, where $T$. dimidiata was likely transported to human dwellings on firewood (Espinoza-Gómez et al. 2002, López-Cárdenas et al. 2005).

More than $75 \%(n=835)$ of the triatomines in this study were collected inside of human houses. This result is similar to that reported for M. longipennis in Jalisco and Aguascalientes and for M. pallidipennis in Estado de Mexico (Licón-Trillo et al. 2010, Martínez-Ibarra et al. 2010a, Medina-Torres et al. 2010), which confirms that these species have adapted to exist in human dwellings in some areas of Mexico (Zeledón 1983). Indeed, approximately 100,000 inhabitants were reported to be infected with T. cruzi (Ramsey et al. 2003). It is likely that close 
vector-host contact inside of human dwellings promoted the increased natural infection indices of triatomines in this study. On the other hand, more than $80 \%(n=26)$ of T. barberi specimens were collected from peridomestic areas and this result is similar to the results of previous studies from areas near Colima and Jalisco. This finding confirms the secondary role of this species in the transmission of $T$. cruzi to humans in western Mexico (Espinoza-Gómez et al. 2002, Breniere et al. 2010).

Infestation indices were low in most locations studied, with the exception of Taretan, where more than one-fifth of the houses examined were infested. Crowding and density indices were also low and were similar to those calculated for the same species in Jalisco, with the exception of $T$. dimidiata. Also similarly to reports from Jalisco, the indices in this study were low in most localities because triatomines were generally collected from only a few houses in each location. These low indices could prove to be advantageous for spraying control efforts to effectively and inexpensively eliminate triatomines from houses (Martínez-Ibarra et al. 2008a, Breniere et al. 2010).

Taking into account each of the entomological indices calculated, the inhabitants of Taretan are at the greatest risk for vectorial transmission of $T$. cruzi. However, the presence of $M$. pallidipennis, M. longipennis, T. barberi and $T$. dimidiata in areas throughout Mexico highlights the potential risk for vectorial transmission elsewhere, as these have been shown to be important vectors for T. cruzi transmission (Cruz-Reyes \& Pickering-López 2006). These data, together with the high infection indices and the large number of people infected (Ramsey et al. 2003) argue that continuous entomological and serological surveillance is required to better understand the routes of $T$. cruzi transmission to human populations within the study area.

\section{REFERENCES}

Alejandre-Aguilar R, Nogueda-Torres B, Cortéz-Jiménez M, Jurberg J, Galvão C, Carcavallo R 1999. Triatoma bassolsae sp. n. do México, com uma chave para as espécies do complexo "phyllosoma" (Hemiptera, Reduviidae). Mem Inst Oswaldo Cruz 94: 353-359.

Bargues MD, Klisiowicz DR, González-Candelas F, Ramsey JM, Monroy C, Ponce C, Salazar-Schettino PM, Panzera F, Abad-Franch F, Souza OE, Schofield CJ, Dujardin JP, Guhl F, Mas-Coma S 2008. Phylogeography and genetic variation of Triatoma dimidiata, the main Chagas disease vector in Central America, and its position within the genus Triatoma. PLos Negl Trop Dis 2: 1-19.

Breniere SF, Bosseno MF, Magallón-Gastélum E, Soto-Gutiérrez MM, Kasten-Monges MJ, Barraza-Salas JH, Romero-Paredes JJ, Lozano-Kasten FJ 2010. Community participation and domiciliary occurrence of infected Meccus longipennis in two Mexican villages in Jalisco state. Am J Trop Med Hyg 83: 382-387.

Carcavallo R, Jurberg J, Lent H, Noireau F, Galvão C 2000. Phylogeny of the Triatominae (Hemiptera: Reduviidae). Proposal for taxonomic arrangements. Entomol Vect 7: 1-99.

Cohen JM, Wilson ML, Cruz-Celis A, Ordóñez RL, Ramsey J 2006. Infestation of Triatoma pallidipennis (Hemiptera: Reduviidae: Triatominae) is associated with housing characteristics in rural Mexico. J Med Entomol 43: 1252-1260.

Cruz-Reyes A, Pickering-López JM 2006. Chagas disease in Mexico: an analysis of geographical distribution during the past 76 years A Review. Mem Inst Oswaldo Cruz 101: 345-354.
Espinoza-Gómez F, Maldonado-Rodríguez A, Coll-Cárdenas R, Hernández-Suárez CM, Fernández-Salas I 2002. Presence of Triatominae (Hemiptera, Reduviidae) and risk of transmission of Chagas disease in Colima, Mexico. Mem Inst Oswaldo Cruz 97: 25-30.

Gómez-Hernández C, Rezende-Oliveira K, Cortés-Zárate A, CortésZárate E, Trujillo-Contreras F, Ramírez LE 2008. Prevalence of triatomines (Hemiptera: Reduviidae: Triatominae) infected by Trypanosoma cruzi; seasonality and distribution in the Ciénega region of the state of Jalisco, Mexico. Rev Soc Bras Med Trop 41: 257-262.

Lent H, Wygodzinsky P 1979. Revision of the Triatominae (Hemiptera: Reduviidae) and their significance as vectors of Chagas disease. Bull Am Mus Nat Hist 163: 123-520.

Licón-Trillo A, Balsimelli De La Peña K, Acosta Legarda M, Leal Solís I, Nogueda-Torres B, Martínez-Ibarra JA 2010. Infección natural por Trypanosoma cruzi en triatominos del Centro y Norte de México. Bol Mal Salud Amb 50: 91-93.

López-Cárdenas J, González-Bravo FE, Salazar-Schettino PM, Gallaga-Solórzano JC, Ramírez-Barba E, Martínez-Méndez J, Sánchez-Cordero V, Townsend-Peterson, Ramsey JM 2005. Finescale predictions of distribution of Chagas disease vectors in the state of Guanajuato, Mexico. J Med Entomol 42: 1068-1081.

Martínez F, Martínez-Ibarra JA, Catalá S, Villalobos G, de la Torre P, Laclette J, Alejandre-Aguilar R, Espinoza B 2010. Natural crossbreeding between sympatric species of the Phyllosoma complex (Insecta: Hemiptera: Reduviidae) indicate the existence of only one species with morphologic and genetic variations. Am J Trop Med Hyg 82: 74-82.

Martínez-Ibarra JA, Grant-Guillén Y, Morales-Corona ZY, HaroRodriguez S, Ventura-Rodríguez LV, Nogueda-Torres B, BustosSaldaña R 2008a. Importance of species of Triatominae (Heteroptera: Reduviidae) in the risk of transmission of Trypanosoma cruzi in Western Mexico. J Med Entomol 45: 476-482.

Martínez-Ibarra JA, Martínez-Grant JA, Verdugo-Cervantes MR, Bustos-Saldaña R, Nogueda-Torres B 2010a. Monitoreo de la presencia de triatominos mediante gallineros en el sur de Jalisco, México. Biomedica 30: 140-145.

Martínez-Ibarra JA, Martínez-Hernández F, Villalobos G, Vences-Blanco MO, Salazar-Schettino PM 2010b. Update on the distribution of Triatoma bolivari and Triatoma brailovskyi (Hemiptera: Reduviidae: Triatominae) in Western Mexico. J Vect Ecol 35: 432-434.

Martínez-Ibarra JA, Salazar-Schettino PM, Nogueda-Torres B, Vences MO, Tapia González JM, Espinoza-Gutiérrez B 2009. Occurrence of hybrids and laboratory evidence of fertility among three species of the Phyllosoma complex (Hemiptera: Reduviidae) in Mexico. Mem Inst Oswaldo Cruz 104: 1125-1131.

Martínez-Ibarra JA, Ventura-Rodríguez LV, Meillon-Isais K, Barajas-Martínez H, Alejandre-Aguilar R, Lupercio-Coronel P, Rocha-Chávez G, Nogueda-Torres B 2008b. Biological and genetic aspects of experimental hybrids from, species of the Phyllosoma complex (Hemiptera: Reduviidae: Triatominae). Mem Inst Oswaldo Cruz 103: 236-243.

Medina-Torres I, Vázquez-Chagoyán JC, Rodríguez-Vivas RI, Montes-de-Oca-Jiménez R 2010. Risk factors associated with triatomines and its infection with Trypanosoma cruzi in rural communities from southern region of the State of Mexico, Mexico. Am J Trop Med Hyg 82: 49-54.

Noireau F, Abad-Franch F, Valente SAS, Dias-Lima A, Lopes CM, Cunha V, Valente VC, Palomeque FS, de Carvalho-Pinto CJ, Sherlock I, Aguilar M, Steindel M, Grisard EC, Jurberg J 2002. Trapping Triatominae in sylvatic habitats. Mem Inst Oswaldo Cruz 97: 61-63. 
Orozco-Mosqueda GE 2003. Trypanosoma cruzi en vectores en Michoacán. In JM Ramsey, AT Lópes, JL Pohls, Iniciativa para la vigilancia y el control de la enfermedad de Chagas en la República Mexicana, Instituto Nacional de Salud Pública, Cuernavaca, p. 179-180.

Pinto-Dias JC, Gonçalves-Diotaiuti L 1998. IWHO/TDR Technical report 811: small correction, proposal. Rev Soc Bras Med Trop 31: 581-583.

Ramsey JM, Ordóñez R, Tello-López A, Pohls JL, Sánchez-Cordero V, Peterson AT 2003. Actualidades sobre la epidemiología de la enfermedad de Chagas en México. In JM Ramsey, AT Lópes, JL Pohls (eds.), Iniciativa para la vigilancia y el control de la enfermedad de Chagas en la República Mexicana, Instituto Nacional de Salud Pública, Cuernavaca, p. 85-103.

Rodríguez-Bataz E, Nogueda-Torres B, Rosario-Cruz R, MartínezIbarra JA, Rosas-Acevedo JL 2011. Triatominos (Hemiptera: Reduviidae) vectores de Trypanosoma cruzi Chagas, 1909 en el estado de Guerrero, México. Rev Biomed 22: 21-27.
SEGOB - Secretaría de Gobernación 2010. [cited 13 October 2010]. Enciclopedia de los municipios de México. Available from: www.e-local.gob.mx/wb/ELOCAL/ELOC_Enciclopedia.

Silveira AC, De Rezende DF, Máximo MHC 1984. Risk measure of domestic transmission of Chagas disease, through a new entomological indicator. Mem Inst Oswaldo Cruz 79 (Suppl.): 113-115.

Villagrán ME, Marín C, Hurtado A, Sánchez-Moreno M, De Diego JA 2008. Natural infection and distribution of triatomines (Hemiptera: Reduviidae) in the state of Queretaro, Mexico. Trans R Soc Trop Med Hyg 102: 833-838.

Villegas-García JC, Santillán-Alarcón S 2004. Role of Meccus pallidipennis Stal, 1872 in the transmission of Trypanosoma cruzi to man in the state of Morelos, Central Mexico. Entomol Vect 11: 349-362.

Zárate LG, Zárate RJ 1985. A checklist of the Triatominae (Hemiptera: Reduviidae) of Mexico. Int J Entomol 27: 102-127.

Zeledón R 1983. Vectores de la enfermedad de Chagas y sus características ecofisiológicas. Interciencia 8: 384-395. 